\title{
STATISTICAL EXPRESS CONTROL OF THE PEAK VALUES OF THE DIFFERENTIAL-THERMAL ANALYSIS OF SOLID MATERIALS
}

\author{
SEMENOV Andriy ${ }^{1}$, BARABAN Serhii $^{1}$, SEMENOVA Olena ${ }^{1}$, \\ VOZNYAK Oleksandr ${ }^{1}$, ZHAHLOVSKA Olena ${ }^{1}$, \\ VYDMYSH Andrii ${ }^{2} \&$ YAROSHENKO Leonid ${ }^{2}$ \\ ${ }^{1}$ Vinnytsia National Technical University, Vinnytsia, Ukraine \\ ${ }^{2}$ Vinnytsia National Agrarian University, Vinnytsia, Ukraine
}

Purpose. Increase of the probability of non-destructive control of structuralsensitive parameters of solid materials on the basis of differential-thermal analysis.

Methodology. The studies were carried out through the justification of the dependence of the peak temperature on the differential-thermal curves on the physicochemical changes in the molecular structure of solid materials.

Findings. The method of non-destructive control of the molecular structure of solid materials is improved, the distinguishing feature of which is a new sign of suitability for the peak values of the thermodynamic process in solid materials, which made it possible to increase the reliability of the non-destructive control. A statistical norm for deciding on the suitability of solid materials was introduced, which made it possible to organize statistical express control of solid materials under conditions of industrial production of electronic devices.

It contains the researches, which were conducted within the project 0117 U007139 «Methods and devices for forming, processing and measuring signals of radio information systems of industrial and military objects», financed by Ministry of Education and Science of Ukraine.

Key words: differential-thermal analysis, solid materials, express control, peak values, statistical criteria, F-test, t-test

\section{References}

1. Osadchuk, O.V., Baraban, S.V. and Semenov, A.O. (2012). The method of input control of structural-sensitive parameters of non-crystalline semiconductors. Visnyk Khmelnytskogo Natsionalnoho Universytetu, 3, 90-93.

2. Osadchuk, O.V., Baraban, S.V. and Semenov, A.O. (2012). Increasing the probability of non-destructive control of structural transformations of noncrystalline semiconductors. Vymiruvalna ta obchysluvalna tehnika $\mathrm{v}$ technologichnyh procesah, 2, 79-82.

3. Osadchuk, O.V., Baraban, S.V. and Semenov A.O. (2012). Mathematical model of autogenerator for determination of phase transformations of solid materials. Visnyk Khmelnytskogo Natsionalnoho Universytetu, 1, 120-125. 
5. Poplavko, U.M., Pereverzeva, L.P., Voronov, S.A. and Iakymenko U.I. (2007): Physical material science: tutorial handbook, Ch. 2: Dielectriki, NTUU «KPI», Kyiv, 392 p.

6. Fesenko A.I., Ishuk I.N. and Shteinbreher V.V. (2008): Methods and devices for the technical diagnosis of thermal protection and radio-absorbing coatings of aerospace vehicles, Mashinostroenie, Moscow, $200 \mathrm{p}$.

7. Clarke, A.R. and Eberhardt, C.N. (2007): Microscopy Techniques for Materials Science, Technosphera, Moscow, $376 \mathrm{p}$.

8. Knotko, A.V., Presniakov, I.A. and Tretiakov, U.D. (2006): Solid State Chemistry, Izdatelskii zentr «Academia», Moscow, 304 p.

9. Kendziro, O., Lifshiz, V.G., Saranin, A.A., Zotov, A.V. and Kataiama, M. (2006): Introduction to surface physics: per. s angl., Nauka, Moscow, 490 p.

\title{
MULTIFUNCTIONAL POWER QUALITY CORRECTION SYSTEM
}

\author{
KOLB Andrii \\ Dnipro University of Technology, Dnipro, Ukraine
}

Purpose. Study the system of electric power quality control based on AVI with PWM in the systems of group feed of electromechanics with the direct-current unibus.

Methodology. The studies were carried out by modeling a power quality management system based on p-q instant energy theory using generalized vectors of current and voltage in the system of coordinates $\mathrm{x}$, $\mathrm{y}$, which rotates synchronously focused on vector voltage.

Findings. The multi-functional speed quality management systems in electric drives with capacitive storage, which allow to compensate inactive components of power and stabilize the voltage, based on AVI with PWM can be built.

High precision and maximum possible action of quality management electricity system is achieved, for a given energy resources, by using relay regulators and by formation of the current control parameter for the instantaneous value of power.

In three-phase symmetrical system of sinusoidal quantities generalized vectors in the plane of complex variable are represented by a vector, which rotates uniformly with angular frequency voltage.

From the results of the study follows that the proposed system compensates inactive components of the full power, practically without delay and with high precision, in case of practically sinusoidal current network. This is because currents that are needed to be compensated are used as the current tasks of relay regulators allocated without delay for the instantaneous value of power. Thus, we achieve the maximum possible performance of the automatic adjustment of power quality for a given power constraints. 